\title{
Conflict among Indigenous Communities and Settler Bengali Community of Chittagong Hill Tracts: Is There a Way to Peace?
}

\author{
Rafia Rahman* \\ Department of Anthropology, Jatiya Kabi Kazi Nazrul Islam University, Trishal-2220, Bangladesh. \\ *Correspondence: rafiarahman.duanthro@gmail.com (Lecturer, Department of Anthropology, Jatiya Kabi Kazi Nazrul Islam \\ University, Trishal-2220, Bangladesh).
}

\begin{abstract}
The Chittagong Hill Tracts (CHT) $)^{\mathrm{i}}$ of southeastern Bangladesh is the most isolated and geographically unique region of the country, with its hilly composition, vast valleys, cascading streams, and rivers. It is also home to at least 11 indigenous communities, each with its distinct language, culture, and traditions, and a large quantity of Bengali settler population. Since the beginning, there has been tension between the indigenous communities and the Bengali settler community residing in CHT. Now, this tense situation is becoming more and more intense with each passing year, where you almost can't have a conversation about CHT without discussing ethnic conflict. Therefore, we need to look for ways out of the current juncture. During my visit to CHT, I found that a lack of understanding between the two entities and unsatisfactory implementation of the 1997 peace accord ${ }^{\mathrm{ii}}$ is causing distrust and frustrations among the ethnic groups, leading them toward increased ethnic violence and eradicating the likelihood of peace further from this hilly region. Therefore, we have to look for ways to foster understanding between the indigenous communities and settler community, in order to create a sense of interconnectedness among them which, in turn, will persuade them to overcome their differences and sympathize with one another. In addition, the unimplemented clauses of the Peace Accord should be implemented as soon as possible to regain indigenous populations' trust and to give them a sense of security on their own ancestral land.
\end{abstract}

Keywords: Chittagong hill tracts, Indigenous communities, Bengali settlers, Ethnic conflict, and Peace.

\section{INTRODUCTION:}

Bangladesh is a South Asian country, which is constantly going through various changes and catastrophes, especially in the Chittagong Hill Tracts region because of its diverse ethnic composition and unique geographical features. This region is also endured with natural resources and has borders with India and Myanmar. So, there are too many variables surrounding this region of Bangladesh which makes its social circumstances that much unique from the rest of the country. Bengalis started migrating and living in $\mathrm{CHT}$ since the British colonizers bought this previously uncharted area under taxation. However, those Bengalis and the indigenous populations seem to live in relative coherence until the government initiatives migrated flocks of Bengalis to CHT after the birth of Bangladesh in 1971, who are referred to as 'Settler Bengalis'. This coupled with the government's failure to give indigenous identity as separate from Bengali identity generated dissatisfaction among the indigenous communities. Since then there has been continuous conflict amongst the indigenous population 
and the settler population. Now, the ethnic conflict in $\mathrm{CHT}$ has become a major concern for Bangladesh and we are no closer to solving this problem than we were 50 years ago. Therefore, we have to address the ethnic crisis in CHT soon, or we may lose the country's most distinctive, culturally, and socially affluent area and dilute our heritage.

\section{METHODOLOGY:}

Working in the Chittagong Hill Tracts, here, I had the additional challenge of gaining access to indigenous territories. It's not an easy task to stroll into a remote indigenous community and talk about, such pressing issues as, the Peace Accord or their relationship with settler Bengalis. They look at strangers with suspicion. And they have good reasons for that. Because of the tension between Bengali settlers and indigenous communities, it's not surprising that indigenous people are suspicious of outsiders. I found the best way to avoid any suspicion is to have someone from the indigenous community introduce you. So, the field area was selected in relation to our local contracts.

I choose my respondents randomly. Although, I had some idea about the range of people I would like to talk to. As my goal was to find some kind of formula that could reduce hostility between Bengalis and the indigenous populations living in $\mathrm{CHT}$ and make their co-existence harmonic, I wanted to talk to members belonging to both tribal and Bengali communities. I, also, wanted to speak with government officials. I thought this would allow me to get a sense of the administrative thoughts on the issue of managing diversity and establishing peace in CHT. In addition, I wanted to meet with local government officials, indigenous authority figures like headmen and karbaris ${ }^{\mathrm{iii}}$.

\section{Ethnic Communities and Conflict in CHT}

Growing up watching and reading Bengali news outlets, I always saw the Chittagong Hill Tracts being represented as a political and ethnic violence-infested area. So, when I first went to CHT for field research, I was considerably nervous. However, my experience was different from anything I was expecting. I only collected enjoyable memories, pleasant conversations, and knowledge about indigenous populations' everyday life that I didn't usually see on media. This experience was also true for my last visit to $\mathrm{CHT}$ when UniversePG I www.universepg.com
I conducted fieldwork in all three of its districts (Bandarban, Rangamati, and Khagrachhari). Nonetheless, there is any way to doubt the presence of political and social instability in this hilly region. I first went to the Chittagong Hill Tracts as a secondyear undergraduate student to study the livelihood pattern of indigenous communities in Lama, Bandarban. Ever since my first encounter with the indigenous populations residing in CHT, I've been fascinated by their close contact with nature in their daily lifestyle, livelihood, rituals, and ceremonies. And, in order to preserve their natural way of living and cultural authenticity, we need to give them their space and sense of security so they can carry on with their traditional ways. But, the ever scaling ethnic conflict situation in the Chittagong Hill Tracts is pushing the indigenous population further away from the safety and security of their ancestral land and, at the same time, obliterating the chance to resolute ethnic conflict to achieve peace in $\mathrm{CHT}$.

Bangladesh government recognizes 12 ethnic groups living in the Hill Tracts. They are Bawn/Bawm, Chak, Chakma, Khyang, Khumi, Lushei/Lushai, Marma (Maghs), Mrus/Mro (Moorangs), Pangkhua/Pankhua, Tangchangya, Tipperas (Tipras), and Bengalis (Ministry of Health and Family Welfare, 2011). They all have their distinctive languages, culture, religious beliefs, and social customs. So, it is understandable that there might be some tension among the diverse ethnic communities. But, the troubling matter is ethnic conflict in CHT has become a conflict between indigenous communities and the Bengali community.

The nature of ethnic conflict in CHT is inlaid in its history (Shelly, 1992; Mohsin, 2002; Nasreen and Togawa, 2002; Uddin, 2012). The CHT was mostly an inaccessible area until the British colonial government decided to bring it under taxation in 1760 (Uddin, 2012). This was the beginning of outside torment for the native populations, who never known oppression or extortion before. The British employed Bengali officials to see through this process. So, the relationship between the indigenous populations and the Bengali population began in an unfavorable condition. Ever since then, there has been tension between these two groups. 
Nonetheless, at the beginning of the 20th century, the British rulers declared the Chittagong Hill Tracts as restricted. This action provided the British Government the opportunity to freely extract resources from CHT and prevented indigenous populations from being acquainted with Bengali politics, economy, and social organizations (Haque, 2015). So, when Bangladesh became an independent country in 1971, the indigenous populations were out of their depth to understand how to navigate themselves within the newly founded nation. The government of Bangladesh did help with the transition when they asked indigenous communities to leave their distinct ethnic identity and become part of the Bengali identity (Haque, 2015; Mohsin, 2002).

In Addition, the government found different excuses to relocate thousands of Bengalis and set up numerous military camps to CHT without any consultations with its native residents whose ancestral land they were taking over. This, along with the Bangladeshi government's failure to recognize indigenous identity as separate from Bengali identity, led to the formation of PCJSS. The goal of this organization was to uphold the collective rights of indigenous populations and establish Jumma identity ${ }^{\text {iv }}$ (Mohsin, 2002; PCJSS, 2020).

PCJSS's movement gradually transformed into a 20 year long armed conflict in CHT that came to an end in 1997 through signing a peace treaty between PCJSS
(Political organization of indigenous peoples) and the government of Bangladesh. So, the treaty was signed over two decades ago, but ethnic conflict in CHT only seems to get worse with time. One of the main components for constant conflict in CHT is that the peace treaty hasn't yet been fully implemented (The Daily Star, December 3, 2020; The Daily Star, December 2, 2016; Mohsin, 2003).

This is creating frustration and agony among the indigenous population. The 1997 Peace Treaty is also responsible for creating chaos amidst the indigenous populations themselves. A part of PCJSS did not think the treaty was fair to the indigenous populations. So they established $\mathrm{UPDF}^{\mathrm{v}}$. Since then the hostility between PCJSS and UPDF is causing conflict within the indigenous communities and stalling indigenous communitys' ability to represent their undivided Jumma identity (Bashar, 2011).

Chakma, Marma, Tripura, Mro, Bawm, Pangkhu, Khyang, Khumi, Chak, Lushai, Tanchangya populations compose the major demographic arena in $\mathrm{CHT}$, or at least that was the case. According to PCJSS, the Bengali population in CHT is rising at an unprecedented rate. If this rate continues the Bengalis would, if not already, become the majority in CHT that has historically been a foreground for indigenous inhabitants in Bangladesh.

\begin{tabular}{|c|c|c|c|c|c|c|}
\hline \multirow[t]{2}{*}{ Year } & \multicolumn{2}{|c|}{ Jumma } & \multicolumn{2}{|c|}{ Bengali } & \multirow[t]{2}{*}{ Total } & \multirow[t]{2}{*}{ Source } \\
\hline & Population & $\%$ & population & $\%$ & & \\
\hline 1871 & & & & & 63,054 & \\
\hline 1881 & & & & & 101,597 & \\
\hline 1891 & & & & & 107,286 & \\
\hline 1901 & & & & & 124,762 & \\
\hline 1911 & & & & & 153,830 & \\
\hline 1921 & & & & & 173,243 & \\
\hline 1931 & & & & & 212,922 & \\
\hline 1941 & 239,783 & 97.06 & 7,270 & 2.94 & 247,053 & Census 1941 \\
\hline 1951 & 269,177 & 93.71 & 18,070 & 6.29 & 287,247 & Census 1951 \\
\hline 1961 & 339,757 & 88.23 & 45,322 & 11.77 & 385,679 & Census 1961 \\
\hline 1970 & -- & --- & 66,000 & --- & 66,000 & JSS statistics \\
\hline 1974 & 392,199 & 77.17 & 116,000 & 22.83 & 508,199 & JSS statistics \\
\hline 1981 & 441,744 & 58.77 & 313,188 & 41.48 & 754,962 & Census 1981 \\
\hline 1991 & 501,144 & 51.40 & 473,301 & 48.60 & 974,445 & Census 1991 \\
\hline 2011 & 845,541 & 52.90 & 752,690 & 47.10 & 1598,231 & Census 2011 \\
\hline
\end{tabular}

Source: PCJSS, 2020 (https://www.pcjss.org/population-in-cht/) 
The crisis in this hilly region has escalated since the emergence of Rohingya refugees in this border area. As the Rohingya population has more similarities to the Bengali population in terms of their physical features, language, and religion, it is easier for them to represent themselves as Bengalis. This has initiated new uncertainties and distrust among the indigenous populations residing in CHT. The members of indigenous communities, I've talked to, described it as an imminent threat to their existence. They asserted the government might use Rohingya people to diminish indigenous ethnic identity even further.

Another constantly rising issue is the grabbing of indigenous communities' land in the name of promoting tourism and development. During field research, I went to visit the Jhagrabil Mouza, the selected site for Rangamati Science and Technology University, and the local indigenous people, I'd talked to, were not happy about the decision at all. In fact, the Chakma, Marma, and Tanchangya ethnic communities living in this region have been opposing the idea since the announcement came in 2001 and made multiple unsuccessful appeals to the government of Bangladesh (Saha, 2020; Barman and Chakma, 2010).

In Jhagrabil, I had an hour long conversation with a middle age woman sipping tea and watching IndianBangla Television series on a 16 inch LED TV. She told me,

\section{"We will never get any compensation if the government establishes a university building on our land; the Bengalis will take over everything. They will cut down our trees and they will push us further into the forests. Then, how will we survive."}

Other people at the tea stall nodded in agreement with her. It seems to me they have lost their faith in the governmental procedures and promises. The unique lifestyle of indigenous populations comes from their closeness with nature and the land they live on. But, time and time again they have lost their ancestral land in the hands of outsiders, the land upon which their survival depends on and they are not even part of the decision making process. Also, not every member of indigenous communities is aware of what the Peace Accord actually says. Their statement is that the UniversePG I www.universepg.com accord was supposed to return their ancestral land, rehabilitate populations who were displaced during the civil war, remove military force from their grounds (The Peace Accord, 1997) and bring a sense of peace and stability to the Hill Tracts. A karbari in Raynachari in Rangamati said,

"I don't know what the peace accord says. I don't understand the processes. I just want my ancestral land back. But, I don't know whether it's going to happen on not."

Indigenous peoples are constantly fearful of the military and lack of accountability toward military actions. Also, the unspoken alliance between the military force and the Bengali community is a massive concern to indigenous safety and security. Prue Marma from Thanchi, Bandarban says,

“The military is one Bengali community's side.

They guard Bengalis when they take over our land. As long as they are here, the Bengalis' won't slow down."

So, the situation of Chittagong Hill Tracts doesn't seem to get any better over time and the newly infused variables are only making the situation more condense. According to PCJSS, there were 47 land related conflicts in CHT (PCJSS, 2021). Therefore we need to look for new grounds to break the tension between the indigenous communities and the Bengali settler community.

\section{How Can We Resolve Ethnic Conflict in CHT?}

Given the circumstances in CHT, resolving ethnic conflict and introducing peace and integration seems a far fetching idea. There are so much mistrust and misunderstanding all around the hills. This situation needs to change before we can talk about building peace. During my study, I've talked to government officials, indigenous community leaders, and general CHT inhabitants about their opinion on how to reduce conflict in the Chittagong Hill Tracts. Below is a recapitulation of the information I've received from my respondents.

- First of all, the government needs to implement the 1997 peace accord to earn back the trust and confidence of our indigenous populations, so they don't feel detained in their own ancestral land. 
- The government needs to include indigenous populations into decision making process. Democratically elected representatives at the administrative level would give people the comfort of knowing their voices are being heard.

- The Chittagong Hill Tracts is a border region. Therefore, the government seems reluctant to remove military forces from the area. However, the government should immediately set strong parameters for military movement and, also, has to hold the military accountable for their actions inside and around all ethnic communities.

- It is evident from the above discussion that indigenous communities perceive the army as a negative force, only there to charge in the command of Bengali settlers. And the indigenous communities have good reasons behind this perception. Diversifying the military force with more indigenous people could be one way to give everyone similar faith in the army and not see them as threats.

- The two political organizations of indigenous populations, PCJSS and UPDF, need to work out their differences and come together. They need to present a united front so the national authority cannot use their conflict as an excuse to prolong military existence within indigenous territories.

- The government and local administration should be more transparent about their refugee management initiatives to eliminate any sense of threat to indigenous identity.

- Most of the Bengali settlers who move to CHT have little to no knowledge about the importance of the traditional lifestyle of our indigenous population on our cultural diversity and our environment. Therefore, the government should endorse educational programs for Bengali settlers so they can learn, understand and appreciate the rich history, traditions of indigenous peoples and their importance in preserving the natural environment.

- Both Pharis and Settler Bengalis should be educated about the history of conflict, so they can find a common ground upon which they can build peace among themselves.

\section{CONCLUSION:}

The Chittagong Hill Tracts has a long and winding history of ethnic conflict. So, understandably peace and integration are going to take some time to achieve. But, the scary part is we don't seem to be any closer to achieving that goal than we were in 1997. The people of Chittagong Hill Tracts need to see some progress so they can believe peace and harmonious existence is possible. The government needs to honor their promise to the indigenous populations and give them back their ancestral land, recognize their indigenous identity as separate from Bengali identity, remove the supreme power of the military from CHT. This will eliminate indigenous populations' fear that they might lose their land and identity at any moment and give them the stability to integrate among themselves. At the same time, the settler population needs to be made aware of the authentic heritage of the hilly region. These provisions may just create an environment within which integration and peace can blossom in the Chittagong Hill Tracts.

\section{ACKNOWLEDGEMENT:}

Author would like to thank the Department of Anthropology of Dhaka University and Professor Dr. Saifur Rashid for providing financial and creative support and the general people, admunistrative officials of Bandarban, Rangamati and Khagrachhari for their generous cooperation.

\section{CONFLICTS OF INTEREST:}

There is no conflict of interest from the authors' end.

\section{REFERENCES:}

1) Bashar, I. (2011). Bangladesh's Forgotten Crisis: Land, Ethnicity, and Violence in Chittagong Hill Tracts. Counter Terrorist Trends and Analyses, 3(4), 1-5. http://www.jstor.org/stable/26350972

2) Chittagong Hill Tracts Peace Accord (CHTPA), 1997.

3) Chittagong Hill Tracts Development Board, (CHTDB), Ministry of Chittagong Hill Tracts Affairs, http://www.chtdb.gov.bd/

4) Chowdhury, B. H. (2002). Building Lasting Peace: Issues of the Implementation of the 
Chittagong Hill Tracts Accord, Program in Arms Control, Disarmament, and International Security, University of Illinois at UrbanaChampaign.

5) CHT, Brief History and Struggle of the people of the Chittaging Hill Tracts. https://www.pcjss.org/cht-history-struggle/

6) Dalem, C. B., \& Chakma, P. (2010). Human Rights Report 2009-2010 on Indigenous Peoples in Bangladesh, Kapaeeng Foundation.

7) Ministry of Health and Family Welfare. (2016). Tribal/Ethnic Health Population and Nutrition Plan for the Health, Population and Nutrition Sector Development Program (HPNSDP) 2011 to 2016. Government of the People's Republic of Bangladesh.

8) Mohsin, A. (2002). The Politics of Nationalism - The Case of the Chittagong Hill Tracts Bangladesh, The University Press Ltd, P. 272. http://www.uplbooks.com/book/politics-national ism-case-chittagong-hill-tracts-bangladesh

9) Mohsin, A. (2003). The Chittagong Hill Tracts, Bangladesh. Lynne Rienner Publishers.

10) Nasreen, Z., \& Togawa, M. (2002). Politics of Development: 'Pahari-Bengali' Discourse in the Chittagong Hill Tracts. Journal of Inter- national Development and Cooperation, 9(1), pp. 97-112.

11) Parbatya Chattagram Jana Samhati Samiti (PCJSS), https://www.pcjss.org/

12) Refugee Review Tribunal, June 2005. Australia.

13) Saha KK. (2020). Dependency among Kautilya's three major ideas: Upaya, Sadgunya, and Prakrti, Br. J. Arts Humanit., 2(2), 24-35. https://doi.org/10.34104/bjah.020024035

14) Shelly, M. R. (1992). The Chittagong Hill Tracts of Bangladesh: The Untold Story, Centre for Development Research.

15) The Daily Star. December 2, 2016. http://www.thedailystar.net/opinion/humanrights/cht-peace-accord-achievement-sinksnegligence-1323739

16) The Daily Star. December 03, 2020. https://www.thedailystar.net/frontpage/news/23yrs-peace-accord-cht-still-plagued-myriad-ills2004789

17) Uddin, N. (2012). Politics of Cultural Difference: Identity and Marginality in the Chittagong Hill Tracts of Bangladesh, South Asian Survey, 17(2): 283-294. https://doi.org/10.1177/097152311201700206

\footnotetext{
i The Chittagong Hill Tracts or abbreviated CHT represent a combination of Bandarban, Rangamati, Khagrachari districts of the Chittagong division of southeastern Bangladesh. The area is inhabited by 12 indigenous communities and a settler Bengali community.

ii 1997 Peace Accord was signed between the government of Bangladesh and PCJSS in order to draw an end to 20 years long civil war in CHT.

iii Karbari is the general term for village chiefs in CHT.

iv Jumma Identity- Jume is a cultivation method used by the indigenous communities of CHT to grow crops in the Hilly regions. Jumma Identity refers to the collective identity of Jume practicing peoples.

${ }^{v}$ UPDF (United Peoples Democratic Front) - A political party created in response to the 1997 Peace Accord signed between PCJSS and the government of Bangladesh.
}

Citation: Rahman R. (2021). Conflict among indigenous communities and settler Bengali community of Chittagong hill tracts: is there a way to peace? Asian J. Soc. Sci. Leg. Stud., 3(2), 35-40. https://doi.org/10.34104/ajssls.021.035040 @ 